\title{
Objective Meat Quality and Volatile Components as a Function of Cooking Temperature in Beef Longissimus lumborum
}

\author{
Joong Ryong $\mathrm{Ji}^{1}$, Kyung Mi Park², Ho Sung $\mathrm{Choe}^{2}$, and Inho Hwang ${ }^{2 *}$ \\ ${ }^{1}$ Paek Kwang C\&C Co., Ltd., Sungnam 462-700, Korea \\ ${ }^{2}$ Department of Animal Science, Insititute of Agricultural Science and Technology \\ Chonbuk National University, Jeonju 561-756, Korea
}

\begin{abstract}
The present paper describes the effect of cooking temperature on objective meat qualities and volatile components in beef longissimus lumborum. Twenty samples of lumbar vertebrae longissimus muscle from Australian Black Angus (grain-fed and chiller aged for $29 \mathrm{~d}$ ) were screened. Samples were cooked at 50,70 or $90^{\circ} \mathrm{C}$ in a pre-heated water bath for $1 \mathrm{~h}$ and uncooked raw samples were used as control. The results revealed that elevating the heating temperature from 50 to $90^{\circ} \mathrm{C}$ led to a significant $(p<0.05)$ increase in WB-shear force, total energy required for WB-shear force, cooking loss, $\mathrm{pH}$ and soluble collagen content, whereas a significant $(p<0.05)$ linear decrease in protein solubility was observed. The results also revealed that the WB-shear force at $70^{\circ} \mathrm{C}$ was significantly $(p<0.05)$ lower than that observed at $50^{\circ} \mathrm{C}$ and $90^{\circ} \mathrm{C}$. However, the effect of temperature on cooking loss and protein solubility was notably $(p<0.05)$ higher at $70^{\circ} \mathrm{C}$. The detectable volatile components were mostly produced from fat oxidation, and temperature effects on the generation of volatile components were significantly $(p<0.05)$ greater for aldehydes (hexanal, benzaldehyde, nonanal and octanal) than for ketones and hydrocarbons (hexane, benzene, decan, toluene and 3-methylnonane).
\end{abstract}

Key words: beef, end-point temperature, WB-shear force, protein degradation, flavor component

\section{Introduction}

Over the last decade beef consumption in Korea has been stable with approximately seven to eight kg per capita while overall meat consumption has been increased from approximately $30 \mathrm{~kg}$ in 1999 to $36 \mathrm{~kg}$ in 2008 (KMTA, 2010). There could be a number of attributable factors, but we cannot deny the failure of developing practical guidelines for cooking procedure for the best palatable meats. During cooking various protein components changes at different rates and to different extend, causing structural and biological alternation such as shrinkage, denaturation, solubilization and destruction of cell membranes and myoskeletal structure (Tornberg, 2005). It has been generally accepted that meat toughness increases in a stepwise way from 40 to $50^{\circ} \mathrm{C}$ and above $65^{\circ} \mathrm{C}$. However, the mechanism(s) has been controversial in that some researchers (Christensen et al., 2000; Mar-

\footnotetext{
*Corresponding author : Inho Hwang, Department of Animal Science, Chonbuk National University, Jeonju 561-756, Korea. Tel: 82-063-270-2605; Fax: 82-063-270-2605; E-mail: inho.hwang @jbnu.ac.kr
}

tens et al., 1982) attributed the first and second steps to thermal denaturation of myofibrillar and collagen components, respectively. On the other hand, other groups (i.e., Bouton et al., 1981) argued in reverse way, or combination of both components (Lawrie and Ledward, 2006).

Obuz et al. (2004) reported that response of muscle to heating temperature depends on collagen contents. The authors demonstrated that high collagen content muscle such as biceps femoris was tenderized at $45-65^{\circ} \mathrm{C}$ and toughened at $65-80^{\circ} \mathrm{C}$. On the other hand, longissimus muscle was tenderized at $45-55^{\circ} \mathrm{C}$ and toughened at above $55^{\circ} \mathrm{C}$. The studies imply that longer cooking at lower temperature softens collagen components. However if cooking time is extended further, greater myofibril toughening and cooking loss could override the beneficial effect of heat solubilization, resulting in tougher meat. On the other hand, Paul et al. (1973) in early seventies reported that changes in the contractile proteins during cooking had immense effect on tenderness than that in collagen. More a recent study (Christensen et al., 2000) reported that changes in myofibrillar component during cooking accounted for approximately $47 \%$ variation in tenderness. Given this, it became obvious that myofibril- 
lar components had a great effect on meat tenderness to some extend and that is related to endpoint cooking temperature and length of heating.

The number and concentration of volatile compounds detected in beef samples are not only affected by reactants such as amounts and concentration of fatty acid, sugars, amino acids and vitamin in meat, but also affected by reaction conditions viz, cooking temperatures and $\mathrm{pH}$. Previous studies reported that the higher cooking temperature generated the more numbers and higher concentration of volatiles due to not only increased formation of lipid-derived compounds, but also many Maillard reaction-derived products such as pyrazines, thiophenones, pyrroles and sulfur-containing compounds (Predie et al., 1998; Ames et al., 2001; Meinert et al., 2007).

In addition to the great effect on eating quality, studies also identified the endpoint cooking temperature significantly induced undesirable changes in meat during cooking including loss of essential fatty acids as a consequence of lipid oxidation (Rodriguez-Estrada et al., 1997; Rotta, 2009; Oliveros et al., 2009) although response of individual fatty acid to heating varies greatly with unsaturated fatty acids are more prone to oxidation (Bou et al., 2001; Badiani et al., 2002). Furthermore, cooking conditions greatly affected concentration of soluble haem iron (Purchas et al., 2003; Prado et al., 2009) and concentration of potentially bioactive compounds including taurine, carnosine, coenzyme Q10 and creatine are significantly decreased as a function of a higher temperature (Purchas et al., 2004). According to the threshold of US doneness, internal temperature ranges from 55 (very rare), 60 (rare), 63 (medium rare), 71 (medium), 77 (well done) to $82^{\circ} \mathrm{C}$ (well well done) (AMSA, 1995). This guideline might reflect consumer preferences of the cooked meat in terms of flavor and texture as well as microbial reduction, but such a guideline does not exist in Korea.

With taking the previous studies on structural and biochemical changes as a function of cooking condition, the current study was designed to evaluate objective meat qualities and volatile components as a function of heating temperature in beef longissimus lumborum (LL) muscle.

\section{Materials and Methods}

\section{Sampling, experimental design and treatment}

A total of twenty lumbar vertebrae LL muscle of Australian Black Angus were used for the preset investigation. Animals were grain-fed and maturity was A-beef; maximum number of permanent incisors is zero category.
Boxed boneless muscles were imported in chilled condition with ultimate chiller ageing for $29 \mathrm{~d}$. The fresh muscles were sampled from the Incheon airport and transported to the meat science laboratory at the Chonbuk National University and stored at $-20^{\circ} \mathrm{C}$ in a freezer until use within a month. The frozen loin samples were thawed at $10^{\circ} \mathrm{C}$ for $48 \mathrm{~h}$ and cut into sub-samples and $\mathrm{pH}$, moisture content, crude fat and fatty acid composition of uncooked fresh meat was checked. In addition, four (4) meat blocks (approximately $350 \mathrm{~g}$ ) were cut in a factorial arrangement within each loin sample for the heating treatments at 50,70 or $90^{\circ} \mathrm{C}$ in pre-heated water bath for $1 \mathrm{~h}$ with a control block which was hold at room temperature (ca. $20^{\circ} \mathrm{C}$ ) for $1 \mathrm{~h}$. Cooking blocks were heated in polyethylene bags after eliminating hand-removable air. Objective meat texture (i.e., WB-shear force, energy required at WB-peak force point, load extension to WB shear force point and total energy for WB-shear force), cooking loss, total and soluble collagen content, protein solubility, the rate protein degradation and volatile components were determined before and/or after cooking for each designed cooked meat.

\section{Objective meat quality, structural traits and bio- chemical analysis}

The $\mathrm{pH}$ was determined in duplicates strictly following the procedure of Bendall (1973). 1-2 $\mathrm{g}$ of finely cut samples were suspended into know volumes (10-times of sample) of $5 \mathrm{mM}$ iodoacetate- $\mathrm{KCl}$ solution and homogenized for $30 \mathrm{~s}$ at 11,000 rpm with a $15 \mathrm{~s}$ break (UltraTurrax T25B, IKA Works Asia Sdn, Bhd, Malaysia). The $\mathrm{pH}$ was measured at $25^{\circ} \mathrm{C}$ with an Orion $3 \mathrm{Star}$ (Thermo Electron Corp., USA) pH meter.

For objective texture profiles, approximately $350 \mathrm{~g}$ block sample (approximately $5 \times 6 \times 7 \mathrm{~cm}, 6-7^{\circ} \mathrm{C}$ ) were placed in plastic bags and cooked in a pre-heated water bath at 50,70 or $90^{\circ} \mathrm{C}$ for $1 \mathrm{~h}$. When core meat temperature reached each designed temperature. Cooked samples were immediately cooled in cold running water at $18^{\circ} \mathrm{C}$ for $30 \mathrm{~min}$. when core temperature was lower downed to approximately $30^{\circ} \mathrm{C}$, the samples were weighed.

Objective texture profiles were determined by an Instron Universal Testing Machine (Model 3342, Instron Corporation, USA) on six to seven pieces core samples with 0.5 inch diameter using a crosshead speed of 400 $\mathrm{mm} / \mathrm{min}$ and a $40 \mathrm{~kg}_{\mathrm{f}}$ load cell. The weights of the meat samples before and after cooking were recorded and the cooking loss was expressed as weight loss which was represented as weight percent in the present study. 
Objective meat color was evaluated with Konica Minolta Spectrophotometer CM-2500d with an $8 \mathrm{~mm}$ measuring port, D 65 illuminant and $10^{\circ}$ observer. Three measurements were taken on the cut surface of the meat that has been bloomed for $30 \mathrm{~min}$. CIE L*, $\mathrm{a}^{*}, \mathrm{~b}^{*}$ values were recorded.

Sarcoplasmic protein solubility measurements were carried out according to the method described by Warner et al. (1997). Briefly, One gram muscle sample was taken in $10 \mathrm{ml}$ of ice-cold potassium phosphate buffer $(0.025$ $\mathrm{M}, \mathrm{pH} 7.2$ ) in a $50 \mathrm{ml}$ conical tube. The mixture was then homogenized twice, each with $4 \mathrm{~s}$ burst and $10 \mathrm{~s}$ break in between with an UltraTurrax T25B (IKA Works (Asia) Sdn, Bhd, Malaysia) at 11,000 rpm. After keeping overnight in ice, samples were centrifuged at $1500 \mathrm{~g}$ at $4^{\circ} \mathrm{C}$ for $20 \mathrm{~min}$. Protein concentration was determined and expressed as $\mathrm{mg} / \mathrm{g}$ tissue. The moisture content of $2.5 \mathrm{~g}$ minced sample was measured in duplicates in an HR73 halogen moisture analyzer (Mettler-Toledo $\mathrm{GmbH}$, Switzerland) set at $105^{\circ} \mathrm{C}$.

Crude fat was determined by the Soxhlet method using petroleum ether as extraction solvent (AMPC Meat and Livestock Australia, 2006). Precisely, $5 \mathrm{~g}$ finely minced sample was placed in an extraction thimble, dried to constant weight at $102^{\circ} \mathrm{C}$ for $5 \mathrm{~h}$, cooled and placed in a Soxhlet assembly. Extraction was carried out with petroleum ether for $6 \mathrm{~h}$. The organic phase (i.e., petroleum ether) was evaporated in rotary evaporator. The flask containing the fat extract was kept for $1 \mathrm{~h}$ in the drying oven set at $102^{\circ} \mathrm{C}$. The crude fat content of the lean sample was reported as the amount of extracted fat and was expressed as the percentage weight of the fresh sample.

Western blotting for degradation of Troponin-T and desmin was conducted as described by Hwang et al. (2004) method with suitable modifications. Muscle tissues were frozen in liquid nitrogen, and later replaced to $-80^{\circ} \mathrm{C}$. Powdered samples in liquid nitrogen were separated on resolving gels of $12.5 \%$ acrylamide with $4 \%$ acrylamide stacking gels (Laemmli, 1970). The gels for western blotting were transferred to Hybond-P ployvinylidin fluoride for $1 \mathrm{~h}$ at $200 \mathrm{~mA}$ and membranes were blocked for $1 \mathrm{~h}$ with TTBS (20mM Tris, $137 \mathrm{mM} \mathrm{NaCl}$, $5 \mathrm{mM} \mathrm{KCl}, 0.05 \%$ Tween 20) containing 2\% ECL advance blocking agent. The bound primary antibodies (Monoclonal anti-desmin (1:2500, Clone DE-U-10, sigma) and monoclonal anti-Troponin-T (1:2500, Clone JTL-12, sigma) were than labeled with rabbit x-mouse IgG or HRP-conjugated. The bound antibodies were visualized by incubating membranes with BCIP/NBT substrate
(Bio-Rad laboratories, CA) or ECL kit (Amersham, UK).

The total collagen content in samples was determined after $16 \mathrm{~h}$ hydrolysis of $2 \mathrm{~g}$ of meat with $7 \mathrm{~N} \mathrm{H}_{2} \mathrm{SO}_{4}$ at $105^{\circ} \mathrm{C}$ using the modified method of Kolar (1990). Hydrolysate was diluted with distilled water to $500 \mathrm{~mL} .2$ $2 \mathrm{~mL}$ of diluted filtrate was taken and mixed with chloramine $\mathrm{T}$ solution in a test tube and left for $20 \mathrm{~min}$ at room temperature. After adding 4-dimethyl-aminobenzaldehyde solution, the mixture was heated at $60^{\circ} \mathrm{C}$ for 15 min and absorbance was determined at $558 \mathrm{~nm}$. For heat soluble collagen content, homogenized meat sample was heated in a $77^{\circ} \mathrm{C}$ water bath for $70 \mathrm{~min}$ in a 3- times dilution of Ringer's solution (Hill, 1966) F followed by centrifugation, residual fractions were hydrolyzed in $7 \mathrm{~N}$ $\mathrm{H}_{2} \mathrm{SO}_{4}$ for $16 \mathrm{~h}$ at $105^{\circ} \mathrm{C}$. After neutralization, the hydroxyproline content of hydrolyzate was determined according to the procedure outlined by Kolar (1990). The amount of hydroxyproline was determined from a standard curve. The collagen content was calculated from hydroxyproline content using the coefficient. Soluble collagen was calculated by the differences between the total and insoluble collagen contents.

\section{Volatile components}

Volatile components were determined by $\mathrm{Ba}$ et al. (2010). One gram of powdered sample was placed in a 40 $\mathrm{ml}$ headspace vial sealed with PTFE-faced silicone septum (Supelco Co., USA) and cooked at a pre-heated water bath maintained at 50,70 or $90^{\circ} \mathrm{C}$ for $30 \mathrm{~min}$ and the control samples were also kept in parallel at room temperature $\left(-20^{\circ} \mathrm{C}\right)$ for the same time period. After equilibration at $60^{\circ} \mathrm{C}$ for $10 \mathrm{~min}$ (Thermo recorder TR-52 T \& D Corp., Japan), SPME needle (Carboxen/PDMS, $75 \mu \mathrm{m}$, Supelco Co., USA) was inserted into the PTFE/silicone septum and the fiber was exposed for $60 \mathrm{~min}$. At the end of extraction, the fiber was retracted and immediately exposed for $10 \mathrm{~min}$ in the GC-MS injector at $250^{\circ} \mathrm{C}$ (Agilent Technologies 6890N, 5973 MSD, USA). Samples were separated by a DB-5MS capillary column, $30 \mathrm{~m} \times$ $0.25 \mathrm{~mm}$ i.d. $\times 0.25 \mu \mathrm{m}$ film thickness (Agilent J \& W Scientific, Model No. 122-5532, Folcom, USA) with a split ratio of $10: 1$ and split flow of $10 \mathrm{~mL} / \mathrm{min}$. Helium was the carrier gas in constant pressure mode at $7.03 \mathrm{psi}$, flow rate of $1.0 \mathrm{~mL} / \mathrm{min}$ and average linear velocity of $36 \mathrm{~cm} /$ second. The area of each peak was integrated using the ChemStation software (Agilent Technologies, Version D.01.00, USA). Integration parameters include $\mathrm{d}$ initial threshold of 15 and peak width of 0.10 . The eluted compounds were initially identified by comparison of their 
mass spectra with those contained in the Wiley Registry of Mass Spectral Data $7^{\text {th }}$ edition (McLafferty, 2000; Agilent part no. G1035B) which contains 390,000 spectra and 316,934 compounds. The NIST Chemistry webBook $6^{\text {th }}$ edition (NIST Standard Reference Database number 69, containing 129,000 mass spectra; http://webbook.nist. gov/chemistry/, 2009) were simultaneously referred to for confirmation of compounds. Secondly, peaks were identified by Kovats indices calculated by applying a series of standard alkanes C8-C20 (Fluka, Cat. No. 04070, New Zealand, Van den Dool and Kratz, 1963). The calculated retention indices were compared with available literature (Machiels and Istasse, 2003) and accessible database on the website (http://www.pherobase.com; El-Sayed, A.M. 2008, The Pherobase: database of insect pheromones and semiochemicals). Peaks were further confirmed by running various authentic compounds; viz., pentanal, hexanal, heptanal, octanal, octenal, nonanal, E-2-hetenal, E-2octenal, E,E-2,4-nonadienal, E,E-2,4-decadienal, E-2-nonenal, phenylacetaldehyde, 2-octanone, 1-octanol, pyrazine, 2-methylpyrazine and 1-pentanol (Aldrich, USA), 1-octen-3-ol, naphthalene, 2-heptanone and 2-hexanone (Fluka, Switzerland) and decanal (Sigma, USA). All the above mentioned chemicals were diluted 100 times with acetone and $1 \mathrm{uL}$ of aliquot was injected to the GC/MS.

\section{Statistical analysis}

Least square means and standard errors as a function of cooking temperature were calculated using a general linear model (SAS Institute, Cary, NC, 2007) and their effects were assessed by Duncan test at 5\% level against animal error term. Model including animal and heating block nested within animal. Principle component analysis was performed to extract significant volatile components with variables of four heating temperatures (SAS Institute, Cary, NC, 2007), and first and second components of loading and scores were plot using a systat package (SYSTAT version 10.2, Systat software Inc. 2002).

\section{Results and Discussion}

\section{Effect of heating temperature on objective meat quality}

The loin sample used in the current study showed crude fat content of approximately $13.0 \%$, but it ranged from 7.6 to $24.3 \%$ (data not shown). These are equivalent to the BMS scores 4 to 7 of the Korean beef grading system (APGS, 2005). Given the fact that fat content in this range had great effect on meat quality (Serra et al., 2004) and the meat samples were directly imported within a lot, the data indirectly mirrors the variability of meat quality although consumer preference was not evaluated in the current study.

The table 1 presents the effects of cooking temperature on biological and physical characteristics of beef longissimus lumborum muscle. All the measurements were made from the sample cooked at a constant temperature for 60 min and cooled in running water. This means that the data reflect alternations in the evaluated traits during cooling and/or difference between the cooking temperatures. At first glance, values for $\mathrm{pH}$, WB-shear force, total energy required for shearing the specimen, cooking loss, total collagen and collagen solubility were increased as cooking temperature was elevated from non-cooked control to $90^{\circ} \mathrm{C}$, while protein solubility was decreased at a higher temperature. The results obtained in the present investigation fully supported the long term finding that degree of doneness (i.e., end-point temperature) is more significant modifier of meat texture than marbling and/or maturity (Parrish et al., 1973). Collectively the results were not surprising as earlier studies showed that meat toughness increases in a stepwise way from 40 to $50^{\circ} \mathrm{C}$ and above $65^{\circ} \mathrm{C}$, although the mechanism(s) has been controversial (Martens et al., 1982; Christensen et al., 2000; Bouton et al., 1981; Lawrie and Ledward, 2006).

On the other hand, previous studies (i.e., George-Evins, 1999) showed that a higher endpoint temperature for the longissimus muscle resulted in a higher WB-shear force and that was attributed to the increased denaturation and/ or coagulation of myofibrillar and sarcoplasmic protein. In addition, Li et al. (2008) more recently demonstrated that shrinkage of myofibril and intramuscular connective tissue, particularly perimysia during cooking resulted in increases of WB-shear force until internal temperature lower than $75^{\circ} \mathrm{C}$ while further cooking between $75-90^{\circ} \mathrm{C}$ lower WB-Shear force as a result of disintegration of perimysial structure. In these regards, a significantly $(p<$ 0.05 ) higher WB-shear force and total energy for shearing the muscle tissue for $90^{\circ} \mathrm{C}$ treatment was not in agreement of the study. In particular, WB-shear force for $70^{\circ} \mathrm{C}$ statistically significantly $(p<0.05)$ lower than that for both 50 and $90^{\circ} \mathrm{C}$ despite the difference in numeric was limited. A significantly $(p<0.05)$ higher WB-shear force with greater $(p<0.05)$ solubility of collagen, degradation of Troponin- $\mathrm{T}$ and desmin than these for meat heated at $90^{\circ} \mathrm{C}$, compared to the $70^{\circ} \mathrm{C}$ treatment, likely indicate that advantage of disintegration of perimysial tissue on WBshear force at the higher heating temperature was overrid- 
den by shrinkage of myofibril and intramuscular connective tissue as well as a higher cooking loss. The collagen content ranges from 1.5 to $10 \%$ of dry weight of muscle tissue and perimysium comprises approximately $90 \%$ of total connective tissue (McCormick, 1999) and thickness of this had a great relationship with chronically age related meat toughness (Fang et al., 1999). In the current study, it was notable that soluble collagen fraction for meat heated at $50^{\circ} \mathrm{C}$ was lower than that for raw meat, while that for both raw meat and heated at $70^{\circ} \mathrm{C}$ was almost identical. Greatly $(p<0.05)$ increased total collagen content with a higher cooking temperature was not expectable because a significantly $(p<0.05)$ higher cooking loss for a higher temperature was reflected. Obuz et al. (2003) reported that holding at $57^{\circ} \mathrm{C}$ for $15 \mathrm{~min}$ during cooking greatly improved tenderness and that was more evidential for biceps femoris muscle than longissimus lumbrom due to its higher collagen content. While an early study (e.g., Machlik and Draudt, 1963) proposed holding temperature between $60-64^{\circ} \mathrm{C}$ for an effective solubilization of collagen component. Though various studies reported slightly different temperatures for inducing solubilization of collagen component, but the temperature ranges from approximately 55 to $65^{\circ} \mathrm{C}$ appear to be an optimum temperature for softening collagens with minimum adverse effects on water-holding capacity and shrinkage of muscle fibre. If that was a case in the current study, a significantly $(p<0.05)$ lower soluble collagen content for $50^{\circ} \mathrm{C}$ treatment compared to other treatments including un-cooked raw meat was not explicable. The technique for determining soluble collagen content comprised of heating at $77^{\circ} \mathrm{C}$ for $70 \mathrm{~min}$ and collects soluble fraction of $1500 \mathrm{~g}$. This suggests that soluble fraction likely reflects susceptibility of collagen molecular at $77^{\circ} \mathrm{C}$ and consequently generates hydroxyproline. The present results in this regard may reflect that solubility of collagen tissue heated at $50^{\circ} \mathrm{C}$ was very limited or diminished (if any) by any reason. If the rationale is accepted the result of significantly $(p<0.05)$ lower WB-shear force for $70^{\circ} \mathrm{C}$ can be a reflection of solubilization of collagen component. During preliminary analysis of dataset, it was of great interest to examine the variation in the measurements of WB-shear force and total energy required for shearing sub-samples for WB-shear force. In the current study 6-7 sub-samples for WB-shear force were measured for each sample and an average was used for final measurement. However, there was a significant variation in coefficient of variation $(\mathrm{CV})$ between the heat treatments. Fig. 2 shows frequency of $\mathrm{CV}$ of WB-shear force and total energy required to WB-shear force. Our findings clearlyexplains that variation in tenderness was diminished as cooking temperature increased. Our results are of great significance as variation in tenderness for final product is important determinant for consumer satisfaction (Alfaia et al., 2010; Oyama et al., 2009). An average $\mathrm{CV}$ of WB-shear force for $90^{\circ} \mathrm{C}$ treatment was approximately 20 while that was doubled for $50^{\circ} \mathrm{C}$.

Christensen et al. (2000) reported that changes in myofibrillar component during cooking accounted for approximately $47 \%$ variation in tenderness and Bouton et al. (1975) suggested that the physical properties of myofibrillar fibers could be affected more significantly by cooking loss. These studies emphasize the importance of cooking loss in tenderness. On the other hand, the signif-

Table 1. Objective meat qualities, $\mathrm{pH}$, cooking loss and collagen contents of longissimus muscle as a function of heating temperatures at 50, 70 and $90^{\circ} \mathrm{C}$ for $60 \mathrm{~min}$ with reference samples hold at room temperature (RT) for $60 \mathrm{~min}$.

\begin{tabular}{|c|c|c|c|c|c|c|}
\hline & \multicolumn{4}{|c|}{ Heating temperature $\left({ }^{\circ} \mathrm{C}\right)$} & \multirow{2}{*}{$\mathrm{SE}$} & \multirow{2}{*}{ F Value } \\
\hline & RT & 50 & 70 & 90 & & \\
\hline $\mathrm{pH}$ & $5.48^{d}$ & $5.65^{\mathrm{c}}$ & $5.80^{\mathrm{b}}$ & $5.84^{\mathrm{a}}$ & 0.0098 & $283.38 * * *$ \\
\hline WB shear force $(\mathrm{kg})$ & $\mathrm{ND}^{1}$ & $2.08^{c}$ & $1.95^{\mathrm{c}}$ & $2.65^{b}$ & 0.1203 & $29.39 * * *$ \\
\hline Energy at WB shear force $(J)$ & ND & $0.115^{\mathrm{b}}$ & $0.079^{\mathrm{c}}$ & $0.103^{\mathrm{b}}$ & 0.0059 & $69.05 * * *$ \\
\hline Extension at WB shear force $(\mathrm{mm})$ & ND & $27.6^{\mathrm{a}}$ & $22.0^{\mathrm{b}}$ & $20.3^{b}$ & 0.2446 & $267.75 * * *$ \\
\hline Total energy for shearing $(\mathrm{J})$ & ND & $0.174^{\mathrm{b}}$ & $0.193^{\mathrm{b}}$ & $0.268^{\mathrm{a}}$ & 0.0095 & $34.54 * * *$ \\
\hline Cooking loss $(\%)$ & ND & $6.8^{\mathrm{c}}$ & $17.1^{\mathrm{b}}$ & $30.6^{\mathrm{a}}$ & 0.3681 & $1235.69 * * *$ \\
\hline Protein solubility & $3.76^{\mathrm{a}}$ & $2.83^{b}$ & $1.41^{\mathrm{c}}$ & $1.12^{\mathrm{d}}$ & 0.0551 & $502.87 * * *$ \\
\hline Total collagen content $(\%$, wet WT $)$ & $0.35^{\mathrm{d}}$ & $0.39^{c}$ & $0.55^{\mathrm{b}}$ & $0.69^{\mathrm{a}}$ & 0.0142 & $124.6 * * *$ \\
\hline $\begin{array}{l}\text { Soluble collagen content }(\% \text {, wet WT }) \\
\mathrm{df}^{2}\end{array}$ & $0.13^{\mathrm{b}}$ & $0.04^{\mathrm{c}}$ & $0.12^{b}$ & $0.26^{\mathrm{a}}$ & 0.0174 & $\begin{array}{l}26.84 * * * \\
3 / 59\end{array}$ \\
\hline
\end{tabular}

$* p<0.05, * * p<0.01, * * * p<0.001$.

${ }^{\text {abcd }}$ Means bearing the same letter did not differ significantly $(p>0.05)$.

${ }^{1}$ Not determined.

${ }^{2}$ Numerate degree of freedom/denominate degree of freedom. 


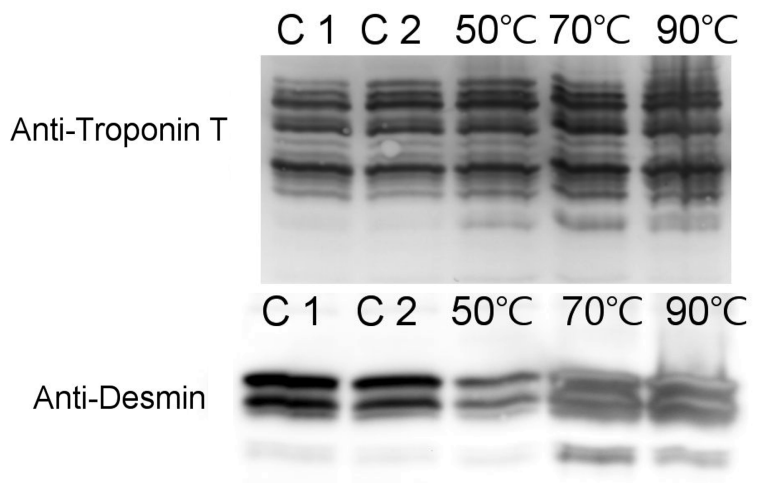

Fig. 1. Degradation pattern of Troponin-T and desmin of longissimus muscle as a function of heating temperature at 50, 70 and $90^{\circ} \mathrm{C}$ for $60 \mathrm{~min}$ with reference samples hold at room temperature $(\mathrm{C} 1, \mathrm{C} 2)$ for $60 \mathrm{~min}$.

icantly tender meat for $70^{\circ} \mathrm{C}$ treatment even with significantly $(p<0.05)$ higher cooking loss than raw meat and $50^{\circ} \mathrm{C}$ treatment demonstrated that collagen solubilization for $70^{\circ} \mathrm{C}$ was linked to the tender meat, and the solubilization overridden the adverse effects of cooking loss on tenderness (Table 1). In particular, it is worthy to note that protein degradation was greatly accelerated from $70^{\circ} \mathrm{C}$ and was more prominent in desmin while Troponin- $\mathrm{T}$ showed obvious degradation from $50^{\circ} \mathrm{C}$ (Fig. 1). This suggested in part that desmin degradation is likely more significantly related to tenderization during cooking. If that was not the case, the result likely mirrors that desmin is more a good indicator for meat tenderness in cooked meat.

Protein solubility was significantly $(p<0.05)$ decreased
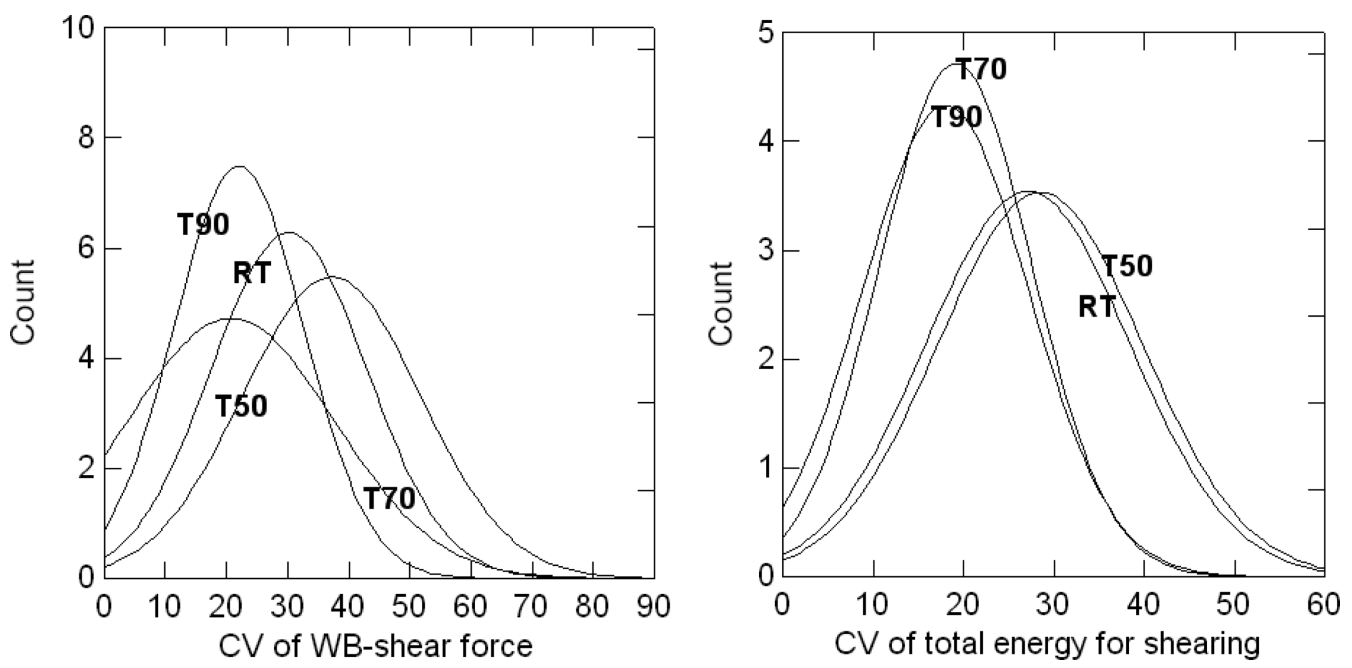

Fig. 2. Distribution and frequency of coefficient of variation (CV) for WB-shear force (left plane) and total energy (right plane) required to shearing longissimus muscle heated at $50(\mathrm{T50}), 70(\mathrm{T70})$ and $90^{\circ} \mathrm{C}(\mathrm{T90})$ for 60 min with reference samples hold at room temperature (RT) for $60 \mathrm{~min}$. as cooking temperature increased, but their magnitude was greatly elevated from $70^{\circ} \mathrm{C}$, in that 25,63 and $70 \%$ of solubility was diminished at 50,70 and $90^{\circ} \mathrm{C}$, respectively, compared to raw meat. The measurement is in fact sarcoplasmic protein solubility (Warner et al., 1997) in a weak and neutral acidity. The data indicates that denaturation of sarcoplasmic protein fraction was limited at $50^{\circ} \mathrm{C}$. This was again confirmed by cooking loss data of which $6.8,17.1$ and $30.6 \%$ for 50,70 and $90^{\circ} \mathrm{C}$, respectively. Our data is in agreement with previous studies (i.e., Hamm, 1986) which reported that loss of waterholding capacity occurs between $60-90^{\circ} \mathrm{C}$ and collagen shrinkage at approximately $70^{\circ} \mathrm{C}$. With these findings it is given to understand thatheating at higher than $70^{\circ} \mathrm{C}$ can promote cooking loss as a consequence of reduction in water-holding capacity and collagen shrinkage. During thermal processing, approximately $20-40 \%$ of total weight is expelled as cooking loss as a consequence of protein denaturation and shrinkage. In fact, shrinkage of muscle takes place by both denaturation of protein and loss of water by which unbalanced pressure between inner and outer side of meat chop. A higher cooking loss for steaks heated at a higher cooking temperature can be attributed to shrinking of muscle fibres in both longitudinal and lateral directions, resulting in expulsion of unbound and free water (Bowers et al., 1987) and these were related capability of water retention, protein denaturation and collagen solubilization (Jeremiah and Gibson, 2003; Laakonen, 1973). Meats with lower $\mathrm{pH}$ had a lower isometric tension of collagen fibres and thus pressure developed by collagen fibres on muscle components decreased (Usha 
and Ramasani, 2000; Kikuhara and Hirooka, 2009), therefore leads to a higher water holding capacity for meat with a high pH (Lewis and Purslow, 1991). In the current study, although $\mathrm{pH}$ after cooking increased significantly $(p<0.05)$, $\mathrm{pH}$ for raw meat was identical and that would barely be reflected on collagen solubility and cooking loss.

\section{Effect of heating temperature on volatile compo- nents}

The Table 2 presents detectable volatile components using SPME-GC/MS technique as a function of heating temperatures at 50,70 or $90^{\circ} \mathrm{C}$ in water bath for $1 \mathrm{~h}$ with reference samples kept at room temperature for the same time period. Under the present experimental conditions a total of 29 volatile compounds including 9 aldehydes, 2 ketones, 3 alcohols, 13 hydrocarbons and 1 furan were detected. All aldehydes and alcohols, and five out of thirteen hydrocarbons significantly $(p<0.05)$ increased with the rise in cooking temperature. These compounds were identified and reported in the literature (Elmore et al.,

Table 2. Contents of detectable volatile components in longissimus muscle using SPME-GC/MS technique as a function of heating temperatures at 50,70 and $90^{\circ} \mathrm{C}$ for $60 \mathrm{~min}$ with reference samples hold at room temperature $(\mathrm{RT})$ for $60 \mathrm{~min}(\mu \mathrm{g} / \mathrm{kg}$ tissue)

\begin{tabular}{|c|c|c|c|c|c|c|c|c|c|c|}
\hline \multirow{2}{*}{ ID } & \multirow{2}{*}{ Compounds } & \multirow{2}{*}{ RT } & \multirow{2}{*}{ LRI } & \multirow{2}{*}{ Reliability $^{1}$} & \multicolumn{4}{|c|}{ "Treatment $\left({ }^{\circ} \mathrm{C}\right)$} & \multirow{2}{*}{ SE } & \multirow{2}{*}{ Sig. level } \\
\hline & & & & & RT & 50 & 70 & 90 & & \\
\hline \multicolumn{11}{|c|}{ Aldehydes } \\
\hline $\mathrm{AH}-1$ & Acetaldehyde & 3.491 & $<800$ & $\mathrm{~ms}$ & 0 & 0 & 8.7 & 10.1 & 0.65 & $p<0.05$ \\
\hline $\mathrm{AH}-2$ & Pentanal & 7.019 & $<800$ & $\mathrm{~ms}, \mathrm{IR}, \mathrm{AC}$ & 0 & 0 & 0 & 37.8 & 0.68 & $p<0.05$ \\
\hline AH-3 & Hexanal & 9.954 & 812 & $\mathrm{~ms}, \mathrm{IR}, \mathrm{AC}$ & 10 & 61.7 & 83.7 & 443.3 & 12.4 & $p<0.05$ \\
\hline AH-4 & Heptanal & 12.795 & 917 & MS, IR & 0 & 8.7 & 13.7 & 65.7 & 7.94 & $p<0.05$ \\
\hline $\mathrm{AH}-5$ & Benzaldehyde & 14.414 & 1098 & MS, RI & 0 & 9.7 & 78.7 & 260.7 & 12.6 & $p<0.05$ \\
\hline AH-6 & Octanal & 15.295 & 1025 & $\mathrm{~ms}, \mathrm{IR}, \mathrm{AC}$ & 7 & 14.3 & 23.3 & 75.7 & 12.9 & $p<0.05$ \\
\hline $\mathrm{AH}-7$ & Nonanal & 17.471 & 1126 & $\mathrm{~ms}, \mathrm{IR}, \mathrm{AC}$ & 42.3 & 67 & 73.3 & 162 & 16.3 & $p<0.05$ \\
\hline AH- 8 & E-2-decenal & 20.448 & 1277 & Ms, RI & 0 & 0 & 0 & 6 & 1.89 & $p=0.132$ \\
\hline AH-9 & Propanal & 12.948 & 926 & $\mathrm{~ms}$ & 0 & 0 & 0 & 27.3 & 3 & $p<0.05$ \\
\hline \multicolumn{11}{|c|}{ Ketones } \\
\hline KT-1 & 2-propanone & 3.907 & $<800$ & $\mathrm{~ms}, \mathrm{RI}$ & 0 & 17.3 & 16 & 11.3 & 5.93 & $p=0.231$ \\
\hline KT-2 & 3-hydroxy,2-Butanone & 7.219 & $<800$ & $\mathrm{~ms}, \mathrm{RI}$ & 46 & 29 & 32.3 & 22.7 & 7.99 & $p=0.282$ \\
\hline \multicolumn{11}{|c|}{ Alcohols } \\
\hline AL-1 & 1-octen-3-ol & 14.759 & 2593 & $\mathrm{~ms}, \mathrm{AC}$ & 0 & 0 & 0 & 27.7 & 3.94 & $p<0.05$ \\
\hline AL-2 & 1-octanol & 16.698 & 1083 & $\mathrm{~ms}, \mathrm{IR}, \mathrm{AC}$ & 0 & 7.3 & 1.7 & 13.3 & 1.22 & $p<0.05$ \\
\hline AL-3 & 2-cyclohexen-1-ol & 16.522 & 1306 & $\mathrm{~ms}$ & 0 & 0 & 0 & 7.3 & 0.17 & $p<0.05$ \\
\hline \multicolumn{11}{|c|}{ Hydrocarbons } \\
\hline HC-1 & Hexane & 4.891 & $<800$ & ms, RI & 19.7 & 93 & 63.3 & 47.7 & 30.5 & $p=0.438$ \\
\hline $\mathrm{HC}-2$ & Benzene & 6.116 & $<800$ & $\mathrm{~ms}, \mathrm{RI}$ & 19 & 79.3 & 0 & 80 & 29.1 & $p=0.192$ \\
\hline $\mathrm{HC}-3$ & Toluene & 9.003 & $<800$ & $\mathrm{~ms}, \mathrm{RI}$ & 6.7 & 15 & 9 & 32 & 4.44 & $p<0.05$ \\
\hline $\mathrm{HC}-4$ & 3-ethyl-2-Methyl-1,3-hexadiene & 15.932 & 1110 & $\mathrm{~ms}$ & 0 & 0 & 0 & 10.3 & 0.7 & $p<0.05$ \\
\hline $\mathrm{HC}-5$ & Propylbenzene & 16.278 & 1199 & $\mathrm{~ms}$ & 0 & 0 & 0 & 3 & 1.5 & $p=0.441$ \\
\hline HC-6 & Undecane & 17.355 & 1121 & $\mathrm{~ms}, \mathrm{RI}$ & 3.7 & 1.7 & 1.3 & 7.3 & 1.67 & $p=0.113$ \\
\hline $\mathrm{HC}-7$ & Dodecane & 19.314 & 1223 & $\mathrm{~ms}, \mathrm{RI}$ & 2.3 & 3.3 & 2.7 & 9 & 2.06 & $p=0.152$ \\
\hline HC-8 & Tridecane & 21.117 & 1323 & $\mathrm{~ms}, \mathrm{RI}$ & 0 & 3.3 & 1.7 & 6.3 & 1.22 & $p<0.05$ \\
\hline HC-9 & Decane & 15.190 & 1002 & $\mathrm{~ms}, \mathrm{RI}$ & 2.7 & 6 & 1.7 & 12.7 & 4.76 & $p=0.407$ \\
\hline $\mathrm{HC}-10$ & 3,5-dimethyloctane & 16.614 & 1075 & $\mathrm{~ms}$ & 0 & 0 & 0 & 5.7 & 1.59 & $p=0.085$ \\
\hline HC-11 & 3-methylnonane & 16.415 & 1062 & $\mathrm{~ms}$ & 6.7 & 3.7 & 5.7 & 7.7 & 3.05 & $p=0.814$ \\
\hline $\mathrm{HC}-12$ & Heptadecane & 15.987 & 1100 & $\mathrm{~ms}$ & 6.3 & 0 & 0 & 0 & 0.6 & $p<0.05$ \\
\hline HC-13 & 2,4-dimehtylheptane & 15.669 & 1056 & $\mathrm{~ms}$ & 6.7 & 0 & 0 & 0 & 1.69 & $p<0.05$ \\
\hline \multicolumn{11}{|c|}{ Furan } \\
\hline$F$ & 2-pentylfuran & 14.989 & 1004 & $\mathrm{~ms}, \mathrm{RI}$ & 0 & 0 & 0 & 28.7 & 5.33 & $p<0.05$ \\
\hline
\end{tabular}



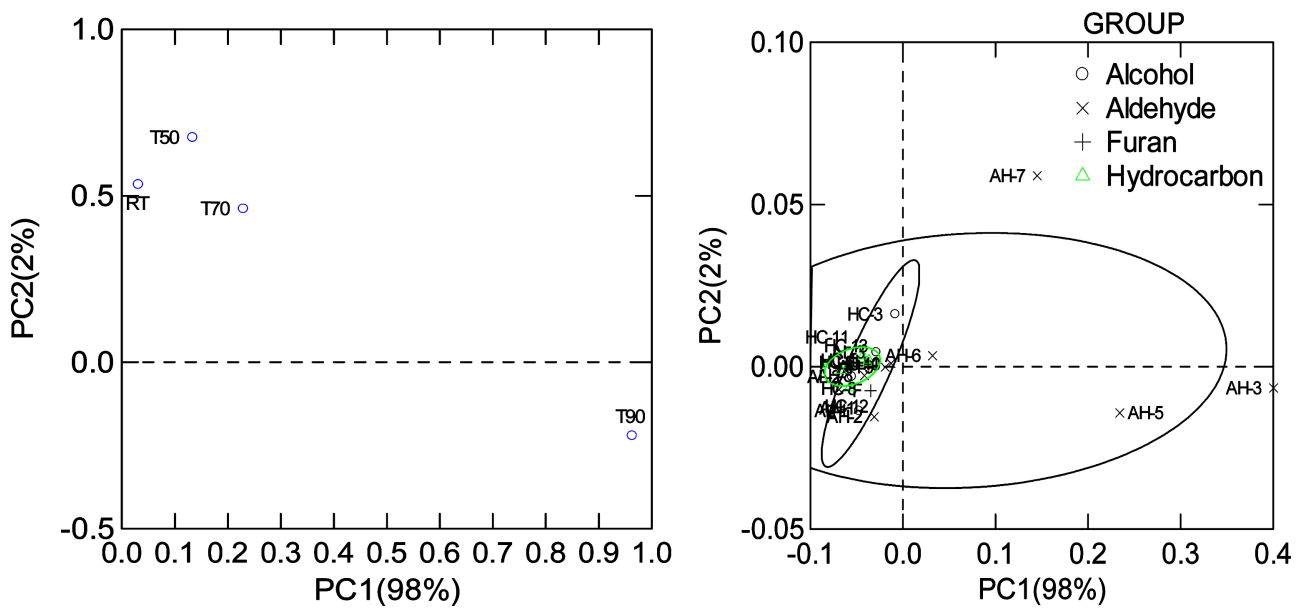

Fig. 3. Plots of principle component analysis of detectable volatile compounds for beef longissimus muscle heated at various temperatures. Loading plots (left plane) of variables for heating temperatures at 50 (T50), 70 (T70) and $90^{\circ} \mathrm{C}$ (T90) for 60 min with reference samples hold at room temperature (RT) for $60 \mathrm{~min}(\mu \mathrm{g} / \mathrm{kg}$ tissue) and score plot of individual volatile components (right plane) listed at table 1 . Values were differently marked between volatile groups. Circles were ellipse lines centered on the sample means of the $\mathrm{x}$ and $\mathrm{y}$ variables at 0.68 .

2004; Insausti et al., 2002; Kim et al., 2002; Raes et al., 2003) and are derived from unsaturated fatty acids oxidative degradation (Elmore et al., 1999, 2002, 2004; Huang and Ho., 2001; Moon et al., 2006) of which hexanal, benzaldehyde and nonanal were the most dominant compounds. Other classes such as sulfur and nitrogencontaining compounds and pyrazine were not detectable and that was likely attributed to the experimental conditions used in this study as above listed compounds are favorably generated at higher cooking temperatures when meat cooked over $100^{\circ} \mathrm{C}$ (Moon et al., 2006). Numbers and concentrations of the detected compounds in our samples were relatively less as compared to other studies (i.e., Raes et al., 2003) where 67 compounds in grilled longissimus lumborum beef including aldehydes, ketones, pyrazines, pyrroles, furane derivatives, thiazoles, sulphur compounds, esters and alcohols classes were reported. However, it is not reasonable to compare our data to others because cooking temperatures in the current study were lower than others. In addition, a constant temperature of dry-oven used for cooking can be one of factors related to less formed volatiles than others using direct heating methods such as grilling, roasting, or stewing. The volatile components were indeed much limited than our database for cooked beef meats cooked at $132^{\circ} \mathrm{C}(\mathrm{Ba}$ et al., 2010).

The number and concentration of volatile compounds detected in beef samples are not only affected by reactants such as amounts and concentration of fatty acid, sugars, amino acids and vitamin in meat, but also affected by reaction conditions including cooking temperatures which plays a very important role in the formation of volatiles. Many previous reports (Ames et al., 2001; Meinert et al., 2007; Predie et al., 1998) have indicated that the more numbers and higher concentration of volatiles formed at the higher cooking temperature is because of increasing the formation of both lipid-derived compounds and Maillard reaction-derived products such as pyrazines, thiophenones, pyrroles and sulfur-containing compounds. In extensive studies, different cooking temperatures affect formation of different chemical classes of volatiles; $180^{\circ} \mathrm{C}$ heating generated more nitrogen and sulfur-containing heterocyclic compounds than $120^{\circ} \mathrm{C}$ heating (Bredie et al., 1998).

A number of earlier studies have shown great diversity of volatile compounds from different breeds, muscle types when cooked at the same temperatures. Machiels et al. (2004) reported 21 volatile compounds in longissimus thoracis muscle of Belgian Blue Limousin and Aberdeen Angus cooked at $150^{\circ} \mathrm{C}$, and significant difference was observed largely in aldehydes (2,4-nonadienal, nonenal, heptanal, 2-methylpropanal, 2-methylbutanal, 2-octenal) and ,3-diethyl-5-methylpyrazine, 2-acetylthiazole, methanethiol, 2-octanone, dimethyl trisulfide, 2,3-pentanedione, ethyl acetate, 2-butanone. On the other hand, significant difference between beef longissimus dorsi of Pirenaica and Friesian cooked at $200^{\circ} \mathrm{C}$ existed mostly in hydrocarbons (3-methyleneheptane, hexane, heptane, 2,2,4,6,6pentamethylheptane, methylcyclohexane), only one aldehyde (butanal) and one sulfur compound (dimethylsulfide) (Gorraiz et al., 2002). Various research group provided the reasons for the differences in different intra- 
muscular fat contents and fatty acid composition. In a study carried out by Stetzer et al. (2008) only two compounds (hexanal and 1-octen-3-ol) were significantly different among muscle types (e.g., mm. rectus femoris, vastus lateralis, vatsus medialis, teres major, infraspinatus, complexus, serratus ventralis, psoas major and longissimus dorsi). Both compounds derived from linoleic acid (C18:2 n-6) degradation (Elmore et al., 2002). From this study it is given to understand that the muscle shows various fiber composition, which implies that flavor components are greatly influenced by fat components rather than fibre composition. In the current study, meats were heated up to $90^{\circ} \mathrm{C}$ and it was found that only lipid-derived products can be formed, rather than protein related products such as Maillard reaction-derived products.

It is predominantly noteworthy that the limited effect of heating temperature on the formation of volatiles at temperature lower than $70^{\circ} \mathrm{C}$ compared to $90^{\circ} \mathrm{C}$, and furthermore the magnitude of the influence on the flavor components varied among the volatiles at the same temperature. The current data revealed that twenty-nine volatile compounds varied among cooking temperature treatments, and the higher cooking temperature generated the more compounds. Twenty-seven of these compounds appeared with higher concentration at $90^{\circ} \mathrm{C}$ heating while some of them were detectable with nearly same concentrations at the other heating conditions (i.e., control, 50 or $70^{\circ} \mathrm{C}$ ) (Table 2). It has been approved that the detected compounds reported in the current study were derived from lipid oxidation and the reaction can occurs lower than $100^{\circ} \mathrm{C}$ (Elmore et al., 1999, 2002; Predie et al., 1998). On the other hand, our data indicated that difference between 90 and $70^{\circ} \mathrm{C}$ heating temperature greatly different from $70^{\circ} \mathrm{C}$ one versus $50^{\circ} \mathrm{C}$ one. Otherwise, the result was likely confounded by the extracting procedure for the determination where in samples were re-heated for $1 \mathrm{~h}$ during absorption onto SPME fiber. This means that samples for control (i.e., raw meat) and $50^{\circ} \mathrm{C}$ treatment were ultimately heated at $60^{\circ} \mathrm{C}$ which is approaching $70^{\circ} \mathrm{C}$ treatment.

One of prominent aspect in the current study was why aldehydes (hexanal, benzaldehyde, nonanal and octanal) are more greatly affected by heating temperature compared to others including ketones and hydrocarbons (Table 2). Aldehydes are the major components detected in volatiles of cooked beef, of which hexanal, nonanal and benzaldehyde had higher concentration than other volatile classes (Elmore et al., 2004; Machiels et al., 2004; Raes et al., 2003). Our results are at par with the previously conducted studies. As aldehydes are the most significant aroma compounds of the lipid oxidative degradation in presence of heat, increased cooking temperature therefore make an increase in concentrations of lipid-oxidized aldehydes. However, if temperature was increased by grilling and roasting methods the aldehydes in cooked meat may become intermediate products and are able to react further with Maillard products to form other volatile classes such as pyrazine, sulfur and nitrogen-containing compounds (Mottram, 1985). With this background it is reasonable to assume that cooking conditions, adopted in the current study, led to the formation of most lipidderived aldehydes while ketones and hydrocarbon compounds seem to be not affected (or less affected if any) with $90^{\circ} \mathrm{C}$ heat treatment. Particularly hydrocarbon compounds (hexane, benzene, decan, toluene and 3-methylnonane) were not influenced by all heat treatments. These compounds have also been detected in previous studies (Gorraiz et al., 2002; Insausti et al., 2002), but it wasn't fully explained how these compounds generated and from where and what factors affect them. This could be assumed that the compounds may be derived from intramuscular fat oxidation as these compounds are present at low level in cooked meats.

The current study collectively demonstrated that elevating heating temperature from 50,70 to $90^{\circ} \mathrm{C}$ significantly increased WB-shear force, total energy required for WBshear force, cooking loss, $\mathrm{pH}$, soluble collagen content while protein solubility linearly decreased. It is noteworthy that WB-shear force at $70^{\circ} \mathrm{C}$ was significantly lower than the other temperatures. More to the point, magnitudes of temperature effect on cooking loss and protein solubility were also greatly prominent at $70^{\circ} \mathrm{C}$ as compared to $50^{\circ} \mathrm{C}$ and the control samples. Detectable volatile components were mostly produced from fat oxidation, and temperature effect on generating volatile components was significantly more prominent for aldehydes (hexanal, benzaldehyde, nonanal and octanal) than for ketones and hydrocarbons hydrocarbon compounds (hexane, benzene, decan, toluene and 3-methylnonane).

\section{Acknowledgement}

It should be acknowledged that this work was financially supported by the research funds of Chonbuk National University in 2010 and Council of Hanwoo check-off fund. Dashdorj Dashmaa and Hoa Van Ba are also thanked for their technical inputs. 


\section{References}

1. American Meat Science Association (1995) Research guidelines for cookery, sensory evaluation and instrumental tenderness measurements of fresh meat: National Live Stock and Meat Board. Chicago.

2. Ames, J. M., Guy, R. C. E., and Kipping, G. J. (2001) Effect of $\mathrm{pH}$ and temperature on the formation of volatile compounds in cysteine/reducing sugar/starch mixtures during extrusion cooking. J. Agric. Food Chem. 49, 1885-1894

3. Ames, J. M., Guy, R. C. E., and Kipping, G. J. (2001) Effect of $\mathrm{pH}$ and temperature on the formation of volatile compounds in cysteine/reducing sugar/starch mixtures during extrusion cooking. J. Agric. Food Chem. 49, 1885-1894.

4. APGS (2005) Korean Beef grading system. Animal Products Grading Service. National Livestock Co-operatives Federation, Seoul, Korea.

5. Ba, H. V., Oliveros, M. C., Ryu, K. S., and Hwang, I. H. (2010) Development of analysis condition and detection of volatile compounds from cooked Hanwoo beef by SPMEGC/MS analysis. Korean J. Food Sci. 30, 73-86.

6. Badiani, A., Stipa, S., Bitossi, F., Gatta, P. P., Vignola, G., and Chizzolini, R. (2002) Lipid composition, retention and oxidation in fresh and completely trimmed beef muscles as affected by common culinary practices. Meat Sci. 60, 169186.

7. Bendall, J. R. (1973) Postmortem changes in muscle. In G. H. Bourne, Structure and function of muscle (2nd ed., Vol. II, Part 2). Academic Press, New York.

8. Boles, J. A. and Swan, J. E. (2002) Heating method and final temperature affect processing characteristics of beef semimembranosus muscle. Meat Sci. 62, 107-112.

9. Bou, R., Guardiola, F., Grau, A., Grimpa, S., Manich, A., Barroeta, A. et al. (2001) Influence of dietary fat source, atocopherol, and ascorbic acid supplementation on sensory quality of dark chicken meat. Poult. Sci. 80, 800-807.

10. Bouton, P. E., Harris, P. V., and Ratcliff, D. (1981) Effect of cooking temperature and time on the shear properties of meat. J. Food Sci. 46, 1082-1087.

11. Bouton, P. E., Harris, P. V., and Shorthose, W. R. (1975) Changes in shear parameters of meat associated with structural changes produced by aging, cooking, and myofibrillar contraction. J. Food Sci. 40, 1122-1126.

12. Bowers, J. A., Craig, J. A., Kropf, D. H., and Tucker, T. J. (1987) Flavor, color, and other characteristics of beef longissimus muscle heated to seven internal temperatures between 55 and $85^{\circ} \mathrm{C}$. J. Food Sci. 52, 533-536.

13. Bredie, W. L. P., Mottram, D. S., and Guy, R. C. E. (1998) Aroma Volatiles Generated during Extrusion Cooking of Maize Flour. J. Agric. Food Chem. 46. 1479-1487.

14. Christensen, M., Purslow, P. P., and Larsen, L. M. (2000) The effect of cooking temperature on mechanical properties of whole meat, single muscle fibers and perimysial connective tissue. Meat Sci. 55, 301-307.

15. Conrad, M. E. and Umbreit, J. N. (2000) Iron absorption and transport-An update. Am J. Hematol. 64, 287-298.
16. Cristina M. M. Alfaia, Susana P. Alves, Anabela F. Lopes, Maria J. E. Fernandes, Ana S. H. Costa, Carlos M. G. A. Fontes, Matilde L. F. Castro, Rui J. B. Bessa, and José A. M. Prates. (2010) Effect of cooking methods on fatty acids, conjugated isomers of linoleic acid and nutritional quality of beef intramuscular fat. Meat Sci. 84, 769-777.

17. Dinardo, M., Buck, E. M., and Clydesdale, F. M. (1984) Effect of extended cook times on certain physical and chemical characteristics of beef prepared in a water bath. J. Food Sci. 3, 844-848.

18. El-Sayed, A. M. (2008) The Pherobase: Database of insect pheromones and semiochemicals. Available from http://www. pherobase.com. Accessed on Oct. 18, 2009.

19. Elmore, J. S., Campo, M. M, Enser, M., and Mottram, D. S. (2002) Effect of lipid composition on meat-like model systems containing cystein, ribose and polyunsaturated fatty acids. J. Agri. Food Chem. 50, 1126-1132.

20. Elmore, J. S., Mottram, D. S., Enser, M., and Wood, J. D. (1999) Effect of the polyunsaturated fatty acid composition of beef muscle on the profile of aroma volatiles. J. Agric. Food Chem. 47, 1619-1625.

21.Elmore, J. S., Warren, H. E., Mottram, D. S., Scollan, N. D., Enser, M., Richardson, R. I., and Wood, J. D. (2004) A comparison of the aroma volatiles and fatty acid compositions of grilled beef muscle from Aberdeen Angus and Holstein-Friesian steers fed diets based on silage or concentrates. Meat Sci. 68, 27-33.

22. Fang, S. H., Nishimura, T., and Takahashi, K. (1999) Relationship between development of intramuscular connective tissue and toughness of pork during growth of pigs. J. Anim. Sci. 77, 120-130.

23. Foster, W., Li, Y., Usas, A., Somogyi, G., and Huard, J. (2003) Gamma interferon as an antifibrosis agent in skeletal muscle. J. Orthop Res. 21, 798-804.

24. George-Evins, C. D. (1999) The effects of quality grade, postmortem aging, blade tenderization, and endpoint cooking temperature on Warner-Bratzler shear force, cooking characteristics, and sensory panel evaluation of longissimus, gluteus medius, and semimembranosus muscles. MS thesis. Kansas State University, Manhattan, KS, USA.

25. Gorraiz, C., Beriain, M. J., Chasco, J., and Insausti, K. (2002) Effect of aging time on volatile compounds, odor, and flavor of cooked beef from pirenaica and Friesian bulls and heifers. J. Food Sci. 67, 916-922

26. Hamm, R. (1986) Functional properties of the myofibrillar system and their measurements. In P. J. Bechtel (ed), Muscle as food, Academic Press, New York, pp. 135-199.

27. Hill, F. (1966) The solubility of intramuscular collagen in meat animals of various ages. J. Food Sci. 31, 161-166.

28. Huang, T. C. and Ho, C. T. (2001) Chapter 4-flavor of meat products. In Meat Science and application. Edited by Hui, Y. H., Nip, W. K., Rogers, R. W., and Young, O. A., Marcel Dekker, New York.

29. Hwang, I. H., Park, B. Y., Kim, J. H. Cho, S. H., and Lee, J. M. (2004) Effects of pre-slaughter fasting and chiller ageing on objective meat quality in longissimus dorsi, biceps femo- 
ris, and triceps brachii muscles of Korean native black pigs. Korean J. Anim. Sci. Technol. 46, 405-414

30. Insausti, K., Beriain, M. J., Gorraiz, C., and Purroy, A. (2002) Volatile Compounds of Raw Beef from 5 Local Spanish Cattle Breeds Stored Under Modified Atmosphere. Food Sci. 67, 1580-1589.

31. Jeremiah, L. E. and Gibson, L. L. (2003) Cooking influences on the palatability of roasts from the beef hip. Food Res. Int. 36, 1-9.

32. Judge, M. D., Aberle, E. D., Cross, H. R., and Schanbacher, B. D. (1984) Thermal shrinkage temperature of intramuscular collagen of bulls and steers. J. Anim. Sci. 59, 706-709.

33. Kherif S, Lafuma C and Dehaupas M. (1999) Expression of matrix metalloproteinases 2 and 9 in regenerating skeletal muscle: a study in experimentally injured and mdx muscles. Dev. Biol. 205, 158-170.

34. Kikuhara, K. and Hirooka, H. (2009) Application of a Simulation Model for Dairy Cattle Production Systems Integrated with Forage Crop Production: the Effects of Whole Crop Rice Silage Utilization on Nutrient Balances and Profitability. Asian-Aust. J. Anim. Sci. 22, 216-224.

35. Kim, Y. H., Nam, K. C., and Ahn, D. U. (2002) Volatile profiles, Lipid oxidation and sensory characteristics of irradiated meat from different animal species. Meat Sci. 61, 257265.

36. KMTA. (2010) Statistics for meat consumption in Korea by years. Available from http://kmta.or.kr/html/sub6-1.html?scode $=11$. Assessed on Mar. 12, 2010.

37. Kolar, K. (1990) Colorimetric determination of hydroxyproline as measure of collagen content in meat and meat products: NMKL collaborative study. J. Assoc. Off. Anal. Chem. 73, 54-57.

38. Laakonen, E. (1973) Factors affecting tenderness during heating of meat. Adv. Food Res. 20, 257-323.

39. Lawrie, R. A., and Ledward, D. A. (2006) Lawrie's meat science (17th ed.). Woodhead Publishing, Cambridge.

40. Lepetit, J. (2008). Collagen contribution to meat toughness: Theoretical aspects. Meat Sci. 80, 960-967.

41. Lewis, G. J., and Purslow, P. P. (1991) The effect of marination and cooking on the mechanical properties of intramuscular connective tissue. J. Muscle Foods 2, 177-195.

42. Li, C. B., Zhou, G. H., and Xu, X. L. (2008) Dynamical changes of beef intramuscular connective tissue and muscle fiber during heating and their effects on beef shear force. Food Bioprocess Technol. DOI 10.1007/s117-3.

43. Li, C. B., Zhuo, G. H., and Xu, X. L. (2008) Dynamical changes of beef intramuscular connective tissue and muscle fibre during heating and their effects on beef shear force. Food Bioprocess Technol. DOI 10.1007/s11947-008-0117-3.

44. Liu, Y. and Chen, Y. R. (2001) Analysis of visible reflectance spectra of stored, cooked and diseased chiken meats. Meat Sci. 58, 395-401.

45. Machiels, D., Istasse, L., and Ruth, S. M. (2004) Gas chromatography-olfactometry analysis of beef meat originating from differently fed Belgian Blue, Limousin and Aberdeen Angus bulls. Food Chem. 86, 377-383.
46. Machlick, S. M. and Draudt, H. N. (1963) The effect of heating time on the shear of beef semitendinosus muscle. J. Food Sci. 28, 711-718.

47. Martens, H., Stabursvik, E., and Martens, M. (1982) Texture and color changes in meat during cooking relating to thermal denaturation of muscle proteins. J. Texture Stud. 13, 291300 .

48. McCormick, R. J. (1999) Extracellular modifications to muscle collagen: Implications for meat quality. Poult. Sci. 78, 785-791.

49. McLafferty, F. W. (2000) Wiley registry of mass spectral data, 7th ed. John Wiley \& Sons, New York.

50. Meinert, L., Andersen, L. T., Bredie, W. L. P., Bjergegaard, C., and Aaslyng, M. D. (2007) Chemical and sensory characterisation of pan-fried pork flavour: Interactions between raw meat quality, ageing and frying temperature. Meat Sci. 75, 229-242.

51. Moon, S. Y., Margaret, A., Cliff, M. A., and Li-Chan, E. C. (2006) Odour-active components of simulated beef flavour analysed by solid phase microextraction and gas chromatography-mass spectrometry and -olfactometry. Food Res. Int. 39, 294-308.

52. Mottram, D. S. (1985) The effects of cooking conditions on the formation of volatile heterocyclic compounds in pork. $J$. Sci. Food Agric. 36, 377-382.

53. NIST Standard Reference Database Number 69. (2009) NIST Chemistry WebBook. Available from http://webbook. nist.gov/chemistry/. Accessed on Oct. 18, 2009.

54. Obuz, E., Dikeman, M. E., Grobbel, J. P., Stephens, J. W., and Loughin, T. M. (2004) Beef longissimus lumborum, biceps femoris, and deep pectoralis Warner-Bratzler shear force is affected differently by endpoint temperature, cooking method, and USDA quality grade. Meat Sci. 68, 243-248.

55. Obuza, E., Dikeman, M. E., and Loughinb, T. M. (2003) Effects of cooking method, reheating, holding time, and holding temperature on beef longissimus lumborum and biceps femoris tenderness. Meat Sci. 65, 841-851.

56. Oliveros, M. C. R., Park, K. M. Kwon, E. G., Choi, N. J., Chang, J. S., I. H. Hwang. (2009) Carcass Traits and the Quality of Meat from Cattle Finished on Diets Containing Barley. Asian-Aust. J. Anim. Sci. 22, 1594-1608.

57. Oyama, K., Fujiwara, S., Katsuta, T., Honda, T., and Mukai, F. (2009) Number of Calves Produced at Specified Age as a Measure of Reproductive Performance in Beef Cattle under Artificially-Inseminated Breeding Scheme. Asian-Aust. J. Anim. Sci. 22, 162-167.

58. Parrish, F. C. Jr., Olson, D. G., Miner, B. E., and Rust, R. E. (1973). Effect of degree of marbling and internal temperature of doneness on beef rib steaks. J. Anim. Sci. 37, 430-434.

59. Paul, P. C., McCrae, S. E., and Hofferber, L. M. (1973) Heat induced changes in extractability of beef muscle collagen. $J$. Food Sci. 38, 66-68.

60. Prado, I. N., Oliveira, A. N., Rotta, P. P., Perotto, D. Prado, R. M., Silva, R. R., Souza, N. E., and Moletta, J .L. (2009) Chemical and Fatty Acid Composition of Longissimus Muscle of Crossbred Bulls Finished in Feedlot. Asian-Aust. J. 
Anim. Sci. 22, 1054-1059.

61. Purchas, R. W., Simcock, D. C., Knight, T. W., and Wilkinson, B. H. P. (2003) Variation in the form of iron in beef and lamb meat and losses of iron during cooking and storage. Int. J. Food Sci. Technol. 38, 827-837.

62. Purchas, R. W., Rutherfurd, S. M., Pearce, P. D., Vather, R., Wilkinson, B. H. P. (2004) Cooking temperature effects on the forms of iron and levels of several other compounds in beef semitendinosus muscle. Meat Sci. 68, 201-207.

63. Purchas, R. W., Rutherfurd, S. M., Pearce, P. D., Vather, R., and Wilkinson, B. H. P. (2004) Concentrations in beef and lamb of taurine, carnosine, coenzyme Q10, and creatine. Meat Sci. 66, 629-637.

64. Raes, K., Balcaen, A., Dirinck, P., Winne, A. D., Claeys, E., Demeyer, D., and Smet, S. D. (2003) Meat quality, fatty acid composition and flavour analysis in Belgian retail beef. Meat Sci. 65, 1237-1246

65. Raes, K., Balcaen, A., Dirinck, P., De Winne, A., Claeys, E., Demeyer, D., and De Smet, S. (2003) Meat quality, fatty acid composition and flavour analysis in Belgian retail beef. Meat Sci. 65, 1237-1246.

66. Rodriguez-Estrada, M. T., Penazzi, G., Caboni, M. F., Bertacco, G., and Lercker, G. (1997) Effect of different cooking methods on some lipid and protein components of hamburgers. Meat Sci. 45, 365-375.

67. Rotta, P. P., Pardo, I. N. D, Prado, R. M. D., Moletta, J. L., Silva, R. R., and Perotto, D. (2009) Carcass Characteristics and Chemical Composition of the Longissimus Muscle of Nellore, Caracu and Holstein-friesian Bulls Finished in a Feedlot. Asian-Aust. J. Anim. Sci. 22, 598-604.

68. Rule, D. C. (1997) Direct transesterification pf total fatty acids of adipose tissue, and of freeze-dried muscle and liver with boron-trifluoride in methanol. Meat Sci., 46, 23-32.

69. SAS. (1997) SAS STAT User's Guide. Statistics. Cary NC.

70. Serra, X., Gil, M., Gispert, M., Guerrero, L., Oliver, M. A., Sañccudo, C., Campo, M. M., Panea, B., Olleta, J. L., Quintanilla, R., and Piedrafita, J. (2004) Characterization of young bulls of the Bruna dels Pirineus cattle breed (selected from old Brown Swiss) in relation to carcass, meat quality and biochemical traits. Meat Sci. 66, 425-436

71. Stetzer, A. J., Cadwallader, K., Singh, T. K., Mckeith, F .K., Brewer, M. S. (2008) Effect of enhancement and ageing on flavor and volatile compounds in various beef muscles. Meat Sci. 79, 13-19.

72. Susan Brewer, M. and Novakofski, J. (1999) Cooking rate, $\mathrm{pH}$ and final endpoint temperature effects on color and cook loss of a lean ground beef model system. Meat Sci. 52, 443151.

73. Tornberg, E. (1996) Biophysical aspects of meat tenderness. Meat Sci. 43, 175-191.

74. Usha, R. and Ramasami, T. (2000) Effect of pH on dimensional stability of rat tail tendon collagen fiber. J. Appl. Polym. Sci. 75, 1577-1584.

75. Van den Dool, H. and Kratz, P. D. (1963) A generalization of the retention index system including linear temperature programmed gas-liquid partition chromatography. J. Chromatogr. 1, 463- 471.

76. Warner, R. D., Kauffman, R. G., and Greaser, M. L. (1997) Muscle protein changes post mortem in relation to pork quality traits. Meat Sci. 45, 339-352.

$\overline{\text { (Received 2010.3.23/Revised 2010.4.21/Accepted 2010.4.22) }}$ 